Western University Scholarship@Western

Centre for the Economic Analysis of Property Centre for the Economic Analysis of Property

Rights. Economics and Law Workshop Papers

Rights

1982

\title{
Arm-Breaking Consumer Credit and Personal Bankruptcy
}

Samuel A. Rea

Follow this and additional works at: https://ir.lib.uwo.ca/economicsceapr_el_wp

Part of the Economics Commons

Citation of this paper:

Rea, Samuel A.. "Arm-Breaking Consumer Credit and Personal Bankruptcy." Centre for the Economic Analysis of Property Rights. Economics and Law Workshop Papers, 82-02. London, ON: Department of Economics, University of Western Ontario (1982). 


\section{ECONOMICS AND LAW WORKSHOP}

No. 82-02

ARM-BREAKING CONSUMER CREDIT AND

PERSONAL BANKRUPTCY

BY

Samue1 A. Rea, Jr. University of Toronto

January 6, 1982

Major funding for the Centre for Economic Analysis of Property Rights has been provided by The Bureau of Corporate Affairs, Consumer and Corporate Affairs, and by the Academic Development Fund, The University of Western Ontario. The views expressed by individuals associated with the Centre do not reflect official views of the Centre, The Bureau of Corporate Affairs, or The University of Western Ontario.

Subscriptions to the Workshop papers and the Working Paper Series are $\$ 40$ per year for institutions and $\$ 25$ per year for Individuals. Individual copies, if available, may be purchased for $\$ 3$ each. Address all correspondence to John Palmer, Centre for Economic Analysis of Property Rights, The University of Western Ontario, London, Ontario, CANADA N6A 5C2 


\section{CONTENTS}

\section{Introduction}

II. The Role of Government in Regulatory Contracts

III. The Insurance Motive

IV. Secured Creditors
A. Incentives for the Buyer to Default
B. Reduction of Risk
C. Incentives for Seller Performance

V. Unsecured Credit and Arm-Breaking

VI. Wage Garnishment

VII. Bankruptcy

VIII. Conclusions

Appendix A: Secured Credit, Tastes Stochastic

Appendix B: Secured Credit, Income Stochastic

Appendix C: Arm-Breaking to Control Moral Hazard

Appendix D: Arm-Breaking as a Signal

Bibliography

Footnotes 


\section{Introduction}

The laws governing consumer credit are subject to criticism from all sides. Consumer advocates argue that the creditor's remedies are much too severe and that bankruptcy procedures are too punitive. At the same time economists tend to view the existing limitations on credit and laws governing personal bankruptcy as unnecessarily increasing the cost of borrowing. This disagreement tends to pit the debtor's interests against the creditor's interest, when in fact the objective of the legal regulation of the debtor-creditor relationship should be to maximize the expected utility of borrowers for a given utility of lenders. In other words the borrower-lender relationship can be viewed as a contract which should be as efficient as possible.

This paper analyzes the creditors' remedies and bankruptcy provisions that would be included in an efficient contract. It is argued that imperfect information and risk have a profound impact on the nature of the contract. More specifically, the ability of a debtor to protect some of his assets from attachment and to discharge his debt through bankruptcy proceedings, can be viewed as implicit insurance for borrowers. This insurance, like most insurance, carries with it moral hazard caused by an inability of creditors or courts to monitor all of the characteristics that influence the probability and size of the borrower's loss. This moral hazard greatly influences the nature of efficient creditors' remedies. Problems created by imperfect information can also lead to suboptimal results in an unregulated market and in some instances these problems suggest an explanation for the observed pattern of government intervention.

Many of the features of our laws are obviously intended to deal 
with the problems associated with multiple creditors. In order to concentrate on some of the most controversial aspects of laws governing the debtor-creditor relationship, this paper deals primarily with situations in which there is only one creditor per debtor, whether secured or unsecured. The discussion is limited to consumer borrowers and personal bankruptcy.

II. The Role of Government in Regulating Contracts

In order to know what sort of government regulation of the contract between debtor and creditor is appropriate, it is useful to review the economic role of contract law, broadly defined to include laws governing contractual relationships. In a world of perfect information, the parties to a contract could negotiate a "Pareto efficient complete contingent contract", which specifies the actions of each party under every contingency. 'The only role for contract laws in this situation is to enforce the remedies in the contract.

There are several reasons why the real world may fail to generate Pareto efficient complete contingent contracts. First, there are costs of writing complete contracts; second, there are costs of predicting possible contingencies; third, there are costs of determining whether or not a.contingency has occurred; and fourth, one of the parties may have imperfect information concerning some important aspect of the transaction. The first two reasons for incomplete contracts suggests that contract law can provide the missing contract terms in situations that were not covered by the actual contract or in which a mistake was made in the formation of the contract. These two reasons do not provide a convincing justification for substantial government involvement 
in credit transactions because these transactions are so frequent that standard form contracts would be used in the absence of government involvement. ${ }^{2}$ The third reason which leads to moral hazard, does not justify government intervention because the cost of monitoring contingencies is present no matter who is doing the monitoring.

The fourth cause of incomplete or non-Pareto efficient contract offers a more likely economic justification for government involvement in the debtoricreditor contract. Asymmetric information can affect. either the borrower or the lender. Borrowers may be deceived concerning the nature of the contract or lenders may be deceived concerning the borrower's financial position. Borrowers may not perceive the implications of certain remedies in the contract and may underestimate the probability of default. Consequently, they might tend to place little weight on the provisions in the contract dealing with the creditor's remedies and place more weight on the cost of borrowing. The mandatory terms specified by the government would correct this deficiency. ${ }^{3}$ Borrowers might also have more information than the lenders concerning the probability of default and yet might be unable to transmit this information credibly to the lender. Desirable borrowers may be able to signal their characteristics, yet it is possible that the signalling activity leads to a market equilibrium which is Pareto inferior. A mandatory reduction in this signalling can make everyone better off under some circumstances. Some examples of this problem will be illustrated below.

What happens when the law alters the terms of a contract that was already efficient? Figure 1 illustrates the market for loans 


\section{FIGURE 1}

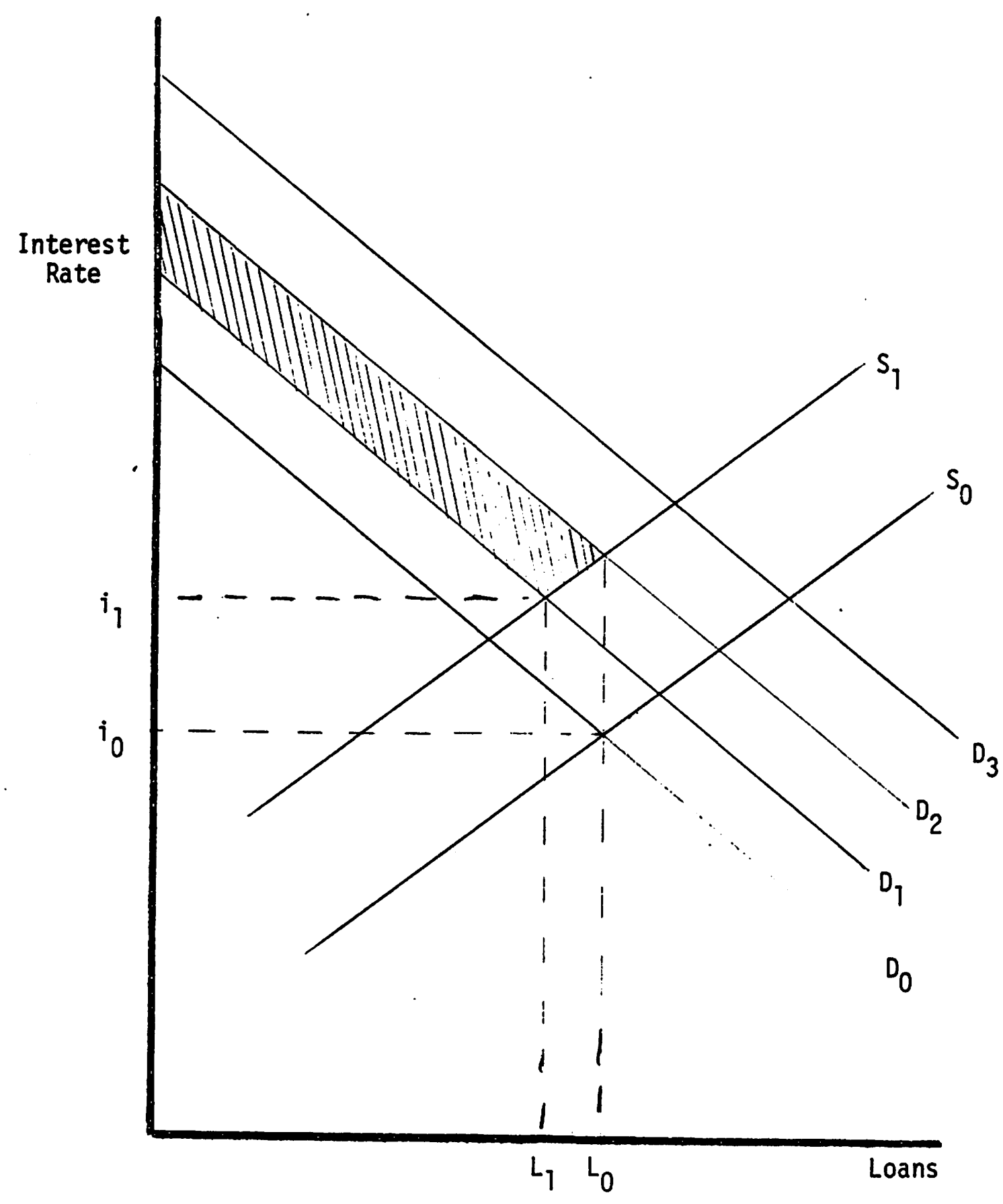


which is initially at an equilibrium in which the interest rate is $i_{0}$ and the total value of loans is $L_{0}$. Assume that the government bans wage garnishment upon default of loans. This raises the cost of lending and shift the supply curve upward to $S_{1}$. At the same time the elimination of garnishment raises the demand for loans from $D_{0}$. to $D_{1}$ because the ex ante cost of default (the cost before it is know who will default) is reduced. Had the demand shifted by the same amount as the supply (from $D_{0}$ to $D_{2}$ ) borrowers and lenders would be in the same position as before in terms of the net borrower and lender surpluses. When the demand curve shifts by less than the supply curve $\left(D_{0}\right.$ to $\left.D_{1}\right)$, the net loss to society is the shaded area in Figure 1. The net loss to society resulting from the introduction of a term in the contract that is valued at less than its cost is shared by borrowers and lenders in the general case, is borne entirely by borrowers if the supply is perfectly elastic, and is borne entirely by lenders if the supply is perfectly inelastic. Borrowers are never better off ex ante as a result of such a policy.

Much of the discussion of the impact of government intervention in credit markets emphasizes the effect on interest rates, ${ }^{4}$ (or credit availability when usury 1 aws are a binding constraint). Figure 1 indicates that the increase in interest rates does not tell us if the policy is desirable. If the value that borrowers place on a particular contract provision exceeds the cost (demand shifts to $D_{3}$ ) interest rates will rise, but consumers will be better off. The appropriate empirical test of the efficiency of a provision is whether loans expand or contract in response to the provision. ${ }^{5}$ This paper attempts to determine the optimal contract provisions from a theoretical model. 


\section{The Insurance Motive}

Consumers frequentiy borrow in order to increase current consumption or in order to finance a consumer durable or a home. ${ }^{6}$ The borrowing allows them to increase expected lifetime utility, but it creates problems if future income is lower than expected or if there lare unusually large future expenses. If a reduction in future income occurs because of random events such as illness or unemployment, the consumer may find it difficult to repay his debts. Ex ante the risk averse consumer would wish to inelude a clause in his loan contract that would allow for partial or total forgiveness of debts if his income falls. If the lender has a large portfolio of loans and if the losses of income of its clients are independent, he will be willing to include such a clause in the contract, provided the interest rate is adjusted upwards by an amount that compensates for the probability of non-payment. Essentially the borrower purchases insurance from the lender when the contract provides that the debt will be forgiven under some conditions.

The insurance motive for bankruptcy has long been recognized. Sir William Blackstone noted that the early laws applied only to traders because "that set of men are, generally speaking, the only persons liable to accidental losses, and to an inability of paying their debts, without

any fault of their own". 7 This quote recognizes that a provision allowing discharge of debts under certain contingencies introduces moral hazard, a common problem in insurance markets. Moral hazard will influence the design of any provision for forgiveness of debts, and it will be carefully considered below, along with adverse selection, another problem caused by imperfect information. 
Why might it be efficient for lending institutions to provide insurance against income fluctuation? Why wouldn't such insurance always be sold by separate insurance companies? When one is dealing with life insurance, medical insurance, disability insurance, property insurance, etc., there are companies that specialize in specific risks, but the risk of a decrease in income or an increase in necessary expenditures that is not covered by these types of insurance is best borne by cre. ditors as compared to other insurance institutions. Consumer creditors are essentially specialists in monitoring the consumer's asset position and his record of repayment. This gives them an advantage in insuring fluctuations in the assets of the consumer. They are also specialists in collection of debts, which can be viewed as the loss control branch of their insurance business. Finally, they are in a position to withhold future credit when there is default. ${ }^{\&}$ Vendors who extend credit are in the best position to mitigate the losses upon default because they are in a favourable position to resell repossessed goods.

What if a creditor does not want to be an insurer? He can pass some of the risk on to insurance companies, particularly the risk of mortality or property loss. "Credit insurance" is the means by which this is accomplished. ${ }^{9}$ Insurance against unemployment can also be purchased, but it is much more expensive. ${ }^{10}$ Vendors can sell their finance paper to finance institutions that specialize in these risks, although often the default risk is borne by the vender through recourse agreements. The law recognizes that some groups of creditors will not be able to diversify against the default risk. For example, wage earners are generally given priority in bankruptcy proceedings and alimony obligations are not discharged by bankruptcy. 11 


\section{Secured Creditors}

The sale of durable goods or housing is frequently accompanied by borrowing from the vendor or a third party with the good that is purchased serving as collateral. Should the buyer cease making payments, the creditor may (in some jurisdictions) repossess the property, sell it, and credit the debtor with the proceeds of the sale less expenses. In many cases the amount that the debtor is credited with is less than the debt outstanding (a "deficiency"), leaving him with a debt despite the loss of the good. This deficiency occurs in part because the resale value of used personal property is lower than the new price and because the property is often sold at a wholesale price. One might expect that the value to the consumer, the amount owed, and the used market value will fall over time as indicated in Figure 2. (It is assumed that there is no downpayment.)

The repossession procedure and the right of the creditor to recover the difference between the net proceeds of resale and the balance owed through a deficiency judgment has been criticized by many consumer advocates. It is argued that the creditor should not be entitled to a deficiency judgement. ${ }^{12}$ (This was apparently the common law approach. ${ }^{13}$ ) Should the deficiency judgement be permitted, it has been suggested that the retail value of the property be credited towards the balance due and that the debtor not be charged with attorney's fees and collection costs. ${ }^{14}$ other proposals would prohibit the repossession when the debtor's equity exceeds 67 per cent, ${ }^{15}$ the total value of personal property falls below some minimum, ${ }^{16}$ or the property is a necessity. ${ }^{17}$

The discussion of these alternatives has generally assumed that the choice of permissible remedies for secured creditors requires one 
FIGURE 2

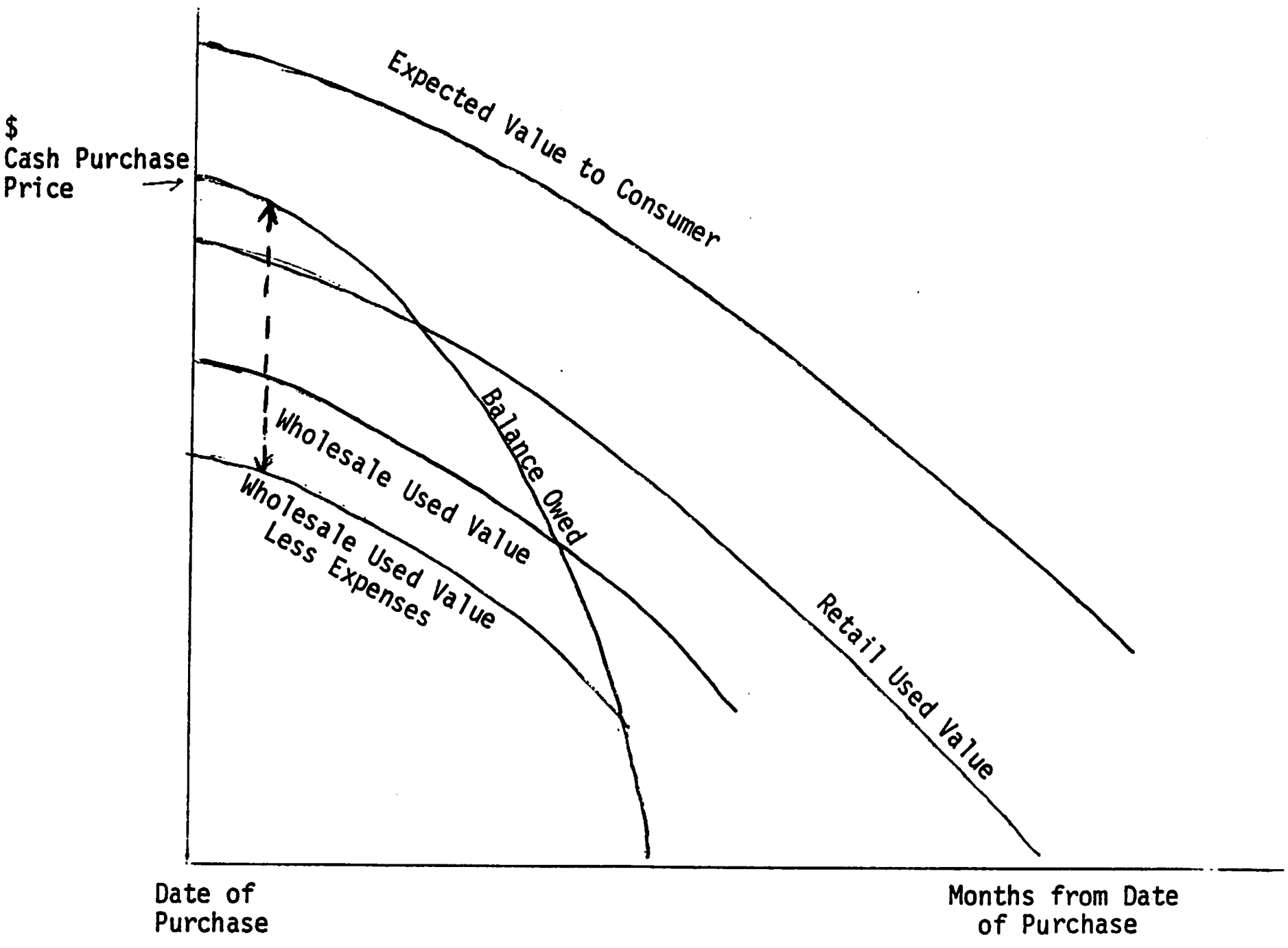


to either favour the interests of the debtor or the creditor. This is not the case. The remedies should be chosen so as to maximize the expected utility of each party, given the expected utility of the other. The partners to the sale in which the goods are to be used as. security will both be served by terms in the contract which recognize the effect of the agreement on the incentive for the buyer to default, the incentive for the buyer to maintain the good, the insurance provided to each party, and the incentive for the seller to honour his obligations concerning the quality of the product or service. These various functions will be analyzed in turn.

\section{A. Incentives for the Buyer to Default}

In the context of consumer transactions, one of the major uncertainies concerns the value that the consumer will place on the consumption of a particular good in the future. If the contract does not recognize this risk, it will be inefficient and will lower the expected utility of consumers. In this section I will assume that both buyers and sellers are risk neutral.

The problem can be illustrated with a simple example. Anticipating a trip to Europe, Arthur S. Smith went into a store and purchased a set of expensive leather luggage. He requested that his initials be engraved on the luggage and stated that he would return a week later to pick up the luggage, at which time he would pay the purchase price. During the week he decided to forego the trip to Europe and purchase a new car instead. When he did not return to pick up the luggage, the seller found out that he was stuck with a set of luggage with Mr. Smith's initials and would have to sell this luggage as used. 
At the time of the contract to purchase the luggage, the following relationships held:

Expected Value to Smith $(E(V))>$ New Price $(S)$
Retail Used Price $(R)>$ Wholesale Used Price $(W)$

Since Smith decided not to purchase the luggage, we must assume that the value that he placed on the luggage fell below the price. If we are concerned with economic efficiency, we wish to have the goods consumed by those who place the highest value on them. The value of the luggage to an alternative buyer is indicated by the retail used price $R$, but in order to transfer the luggage from Smith to the additional buyer, selling costs equal to $R-W$ must be incurred. Efficiency will be achieved by selling the goods to someone else whenever $V$ falls below $W$ and by having Smith take the goods when $V$ exceeds $W$.

If we allow Smith to escape without liability to the vendor, he will decline to pay for the luggage whenever $V$ falls below $S$. There will be some probability that the value that he places on the luggage exceeds the value to the alternative customer but falls short of $S$. In this situation the seller will offer to sell at a price above $W$ in order to cut his losses, but in the future will ask for a non-refundable deposit equal to $S-W$. If Smith is liable for the seller's damages, S-W, Smith will cut his losses by paying for the luggage whenever $S-V<S-W$, or $V>W$. In other words the luggage finds its way to the highest valued use if the seller is compensated for his losses. 
The installment sales contract has the same characteristics as the luggage example. The value that the consumer places on goods will depend on his future tastes and income. Once a consumer take possession of a durable good its market value falls considerably. Furthermore, there are real costs associated with transferring the good from one consumer to another. These costs include repossession costs, attorney's fees, court costs, and costs of resale. Efficiency will be achieved by transferring the good to another consumer whenever the value that the first consumer places on the good falls below the used wholesale price net of collection costs and attorney's fees. In other words, the consumer should pay all of the costs associated with default, ${ }^{18}$ and should be liable for the deficiency if his equity in the good is insufficient to cover the balance due plus these costs. This result is formally derived in Appendix A. This rule has the advantage of encouraging efficient default and the added advantage that it encourages the consumer to maintain the good in order to increase its resale value in the event of default as well as its value to him.

What happens if deficiency judgments. are banned? As in the luggage example, the logical response would be for the seller to require a downpayment that would be such that the balance due would always equal the used wholesale price less expenses of repossession. The debtor would have to borrow from an unsecured lender in order to make the downpayment. Upon default the unsecured creditor would be owed the amount previously owed to the secured creditor (the deficiency). The ban on deficiency judgements would impose an additional transaction cost associated with the second unsecured loan. If the transaction cost is 
high enough, the seller may omit the downpayment requirement and raise the interest rate to cover the additional losses. The result would be higher payments and more default. Additional defaults occur because the lack of deficiency judgments and higher debt outstanding make it more likely that the value that the consumer places on the good will fall below the amount owed. All credit customers will be worse off ex ante.

\section{B. Reduction of Risk}

The suggestion that debtors in default should bear the cost of repossession and resale is troublesome to many observers. Only ten states in the U.S. permit a clause to be included in a small loans contract that imposes attorney's fees on the debtor in the event of default. 19,20 The U.S. FTC recommended that defaulting creditors not pay attorney's fees because borrowers are "better able to bear these costs as a whole than are those individuals who were unable to meet their debts even before attorney's fees were added to them." 21 This quotation does not mention the fact that the fees might be low if the debtor voluntarily relinquished the collateral, but the notion of risk sharing that is implicit in the statement is important. The debtor faces the risk of a change in the value of the good because of changes in tastes or income. The conclusion that the efficient contract would call for the debtor to be credited with the used wholesale price less expenses holds only if there is no risk aversion. Appendix $A$ analyzes the situation in which the tastes are a random variable, the buyer is risk averse and the seller is risk neutral. It will not usually be possible to have simultaneously optimal insurance and optimal default incentives.

If the borrower faces the risk that there is a fluctuation in the 
price of the good or a substitute, the borrower will default whenever $?$ the price of a perfect.substitute falls below the amount credited after repossession. As long as he continues to consume the substitute after default, it makes no sense to credit him with anything but the current wholesale price less expenses. This simultaneously discourages wasteful transactions and perfectly insures the debtor. This argument is the same as the widely understood idea that an investor reduces the risk of fluctuations in his consumption when he invests in his own housing.

When income is a random variable (and tastes are constant) the debtor may wish to default when his income falls below the level at which consumption of the good is desirable. If there is such an income level, there must also be diminishing marginal utility of income and risk aversion. The amount credited to the debtor must provide insurance as well as encourage efficient default. Since the amount credited on default is providing insurance as well as incentives, the rule in which the defaulter pays all costs will generally not be efficient. In Appendix B a model of random income is presented and the amount that should be credited to the defaulting debtor is derived. The result is a compromise between the insurance and incentive objectives. The optimal amount credited to the balance owed will depend on the entire probability distribution of income as well as the utility function. The greater the debtor's risk aversion the higher the amount credited. The probability density in the neighborhood of the critical income level at which default occurs has a particularly strong impact on the optimal contract. If few debtors are likely to be in this range, the amount credited can be set higher without a severe effect on the number of defaults. 
The conclusions are somewhat different if the good is a "necessity". An economic interpretation of an absolute necessity is a good that will be purchased before other goods when income is low and will not be consumed in greater quantities when income increases. In other words the income effect is zero, and the good will be consumed as long as income exceeds the price. Since no one earning more than the price will default, insurance can be provided by crediting the defaultor with the retail price and not permitting a deficiency judgment.

The finding concerning necessities may explain why some goods are treated differently than other assets under Canadian law. In some provinces, deficiency judgments are not permitted for homes or consumer goods. 22 The United States National Commission on Consumer Finance recommended that no deficiency judgment be allowed if a seller-creditor repossesses a good that sold for less than $\$ 1,765.23$ This approach is not a very efficient way of providing insurance. When the consumer has sufficiently low income, he defaults and has neither the "necessity" nor the income to replace it. The problem with this approach is that the insurance is triggered by default and repossession rather than by low income itself. A preferable approach is to prevent repossession of necessities and force creditors to recover through the procedures applicable to unsecured creditors, such as wage garnishment. General exemptions from execution and limitations on wage garnishment provide insurance based on the debtor's overall asset and income position. If the debtor's income has fallen sufficiently, he will be bankrupt and the discharge procedure will provide insurance. This procedure may be a preferable way of tailoring insurance coverage to the actual loss. I conclude that the Ontario Law Reform Commission's recommendation that secured creditors 
be prohibited from seizing assets that are otherwise exempt from execution is appropriate, ${ }^{24}$ but the choice of the exemption should be based on insurance principles. ${ }^{25}$ This issue will be discussed later in the paper.

\section{Incentives for Seller Performance}

In some sales contracts the vendor may make promises with respect to the performance of the good or the maintenance service that will be provided. If the seller is to have an incentive to perform, he must be faced with the total cost of non-performance. This cost must include the consumer's cost of pursuing a claim for damages. If the seller fails to perform his obligations, it might seem logical for the buyer to withhold payment, but this could trigger repossession and the loss of the difference between the value of the good to the buyer and its value to the market, net of expenses. At the very least, the buyer must be able to recover these losses should a court subsequently find that the seller hadbreached his contract. This process can be streamlined if the debtor can raise the issue of creditor breach at a hearing prior to repossession. In order to provide appropriate incentives, the debtor should pay for the cost of the proceedings should he lose. ${ }^{26}$ This rine of reasoning suggests that wage assignments should be permitted (subject to exemptions applicable to wage garnishment) but that the debtor should be able to suspend the assignment when seller default is alleged. 


\section{Unsecured Credit and Arm-Breaking}

Since lenders will often ask for collateral if the borrower has any assets other than his human capital, the unsecured creditor must hope to be repaid out of the borrower's earnings. Given that it may be costly or impossible to garnish this income, the lender must relay on other means of encouraging repayment. Failure to repay could occur because the borrower had no intention to honour the contract or because circumstances changed so as to make it too costly to honour the contract. The most efficient loan contract will be one in which those who have experienced a significant increase in the cost of repayment (a decrease in income) default, and all others repay the loan. Ideally, there would be a penalty for non-payment that would be imposed only on those in the second category who default. The penalty, such as a broken arm, would be sufficient to deter anyone from fraudulently claiming that he could not pay. However, it is frequently difficult to distinguish the two groups of debtors be: cause the loss of income or increase in expenses that will provide an excuse for non-payment may be unobservable by the creditor. This creates one type of moral hazard.

The inability of a lender or third party to monitor the loss of income would appear to eliminate the efficiency of a contract provision that would forgive debts in some circumstances, yet this is not the case. It is shown in Appendix $C$ that for a sufficiently large loss of income it will not be efficient to require repayment in all circumstances. A preferable contract would forgive some or all of the debt and impose a penalty for non-payment, such as a broken arm. ${ }^{27}$ The severity of the penalty would be set so as to discourage any borrower from falsely claiming that he had experienced a decrease in his income, yet ex ante and 
ex post the borrower is better off under this type of contract than under a contract that is backed up by a penalty sufficient to deter non-payment in all circumstances. ${ }^{28}$

The model described in Appendix $C$ shows that in the absence of information on the borrower's cost of repayment it is efficient to inflict some non-monetary penalty on debtors who default, but to forgive: some or all of their debts. Arm-breaking or some other sanction such as social ostracism eliminates the moral hazard problem associated with the implicit insurance. Although courts do not enforce arm-breaking contracts, the law does permit those collecting debts to harass the debtor in numerous ways ${ }^{29}$ The arm-breaking model offers some insights into the appropriate amount of such harassment. The efficient amount of collection will be determined by the costs and benefits of increased harassment of debtors. For example, increased harassment raises collection costs and reduces the utility of debtors who are not meeting their obligations. Yet the harassment leads to the collection of additional funds which lower the cost of borrowing for all debtors. A less obvious advantage of harassment is that it controls the moral hazard associated with debt forgiveness and, if appropriately chosen, raises the expected utility of all borrowers. The arm-breaking model can be used to determine the appropriate collection effort. Ignoring costs of collection, the harassment must be such that those who have not suffered a loss of income are indifferent between paying and not paying their loans. ${ }^{30}$ The greater the amount of the loan forgiven, the greater the efficient amount of harassment. The model illustrates that the harassment agreed to by borrowers and lenders is not intended to induce repayment for all borrowers but merely to deter inefficient non-payment. 
Will the market produce the optimal amount of harassment? Obviously it would be expensive for a contract to specify exactly the types of harassment that could be permitted, but one would expect a standard form contract to arise. In the absence of penalities for breaching the harassment provisions, the creditor has an incentive ex post to increase the level of harassment if it is inexpensive relative to the amount that is collected. More stringent ex post control of harassment may be required if harassment becomes cheaper because of technological change. For instance, computers can now make telephone calls and carry on a "conversation". This makes it possible to harass debtors at a very low cost and will require new provisions in the standard debtor-creditor contract to control the use of this technique.

There is a more fundamental reason why the market may provide an excessive amount of arm-breaking and why government 1 imitations on its use may be efficient. Arm-breaking may perform a signalling role in an unregulated credit market. Low risk borrowers may voluntarily offer to have their arms broken upon default as a signal that they will in all likelihood repay their loans. Higher risk borrowers will be reluctant to offer such a contract because of the greater probability of default. Appendix $D$ explains the implications of such behavior for credit markets. It is shown that the market may generate too much signalling and that all borrowers may be made better off ex ante if there is a ban on this signalling.

The possibility of excessive signalling may explain why there is a government role in limiting various creditors' remedies to what is necessary to discourage inefficient default. The fact that at the time of a 
loan an individual may find it in his interest to voluntarily forego the right to discharge following bankruptcy does not mean that it is inefficient to ban such a contract. The debtor may be better off if he is prevented from signaliing in that manner.

VI. Wage Garnishment .

In light of the previous discussion, it should be clear that insurance based directly on income will avoid many of the problems associated with attempts to provide insurance when income is not monitored directly. Garnishment of earnings allows the amount paid to be directly related to income and eliminates the problem of refusal to pay by those who have income. It does not completely solve the insurance problem. Ideally, the maximun garnishnent would be related to tile-reciuction in the individual's income and the increase in his non-discretionary expenses. The maximum wage garnishment influences the amount of unsecured lending. If the maximum garnishment is 30 per cent, the lender is unlikely to want to lend an unsecured amount on which the payments exceed 30 per cent of the debtor's income. If his income falls, the debtor does not have to make full payments as long as his income is low. This reduction in payments provides implicit insurance. Since insurance is provided when the scheduled payments exceed the maximum garnishable earnings, the lower the amount garnished, the more implicit insurance.

Another reason for making the garnishment less than 100 per cent is the impact of the reduction in net earnings (after garnishment) on labour supply. In Figure 3 , the wage earner is at $A$ enjoying $H_{0}$ hours of leisure and working $\mathrm{T}-\mathrm{H}_{0}$ hours. $\mathrm{CAE}$ is his budget constraint. 
FIGURE 3

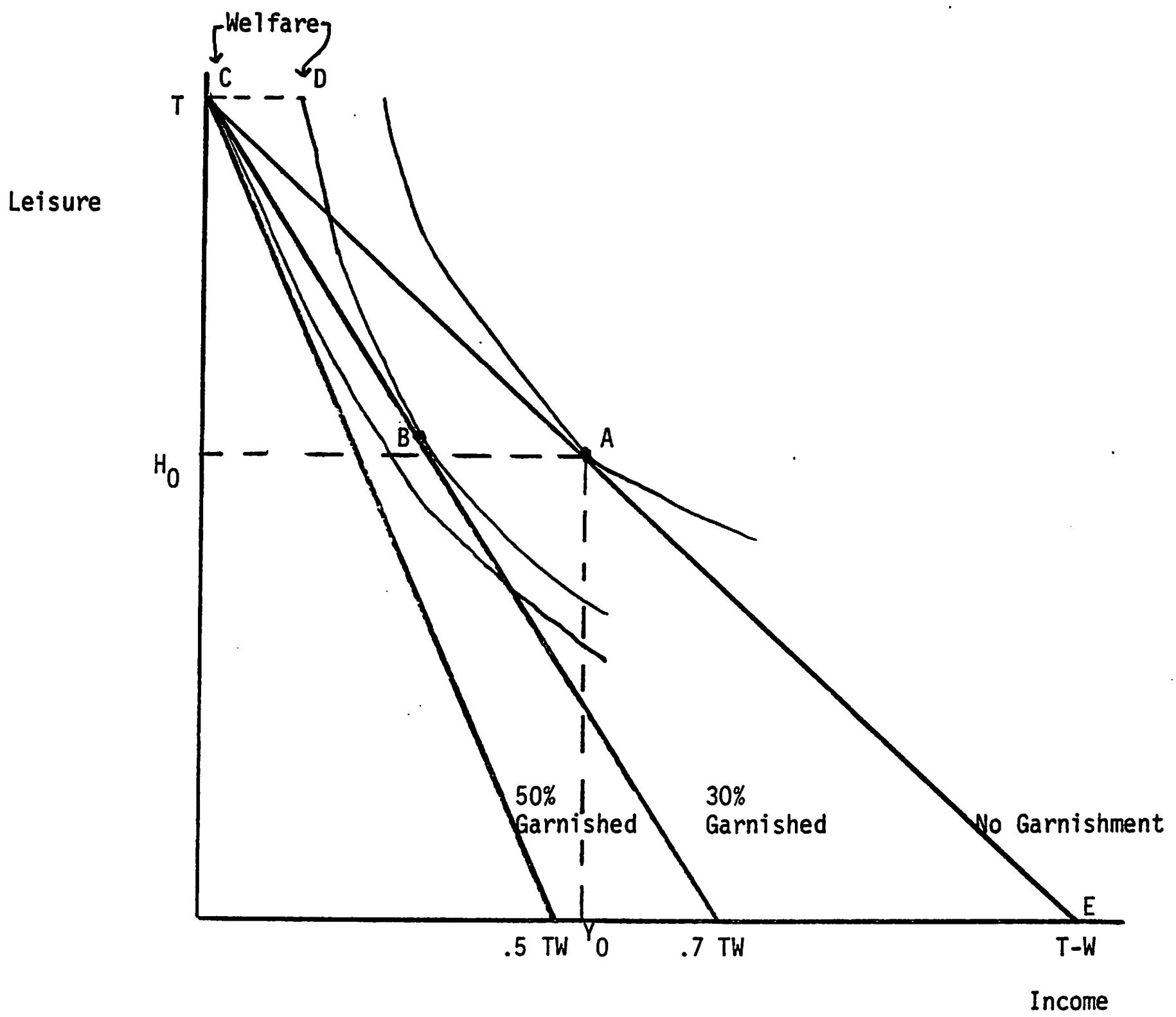


If 30 per cent of his earnings is deducted from his paycheque and there is no other way that the creditor could have recovered his money, the net income is reduced by 30 per cent, just as if he were taxed. In Figure 3, his work falls as he substitutes leisure for income, but work may also. increase. Regardless of the direction of the response, there is a real cost associated with the "tax". In the extreme case, if garnishment is sufficiently great (50 per cent in Figure 3), the debtor will quit his job because the combination of no income and full leisure is preferable to all other possibilities. The existence of welfare benefits complicates the decision. If welfare or unemployment benefits equal $C D$, conditional on no employment income, 30 per cent is the maximum garnishment for the worker in Figure 3. He is indifferent between working (B) and not working (D). Trebilcock and Shulman $(1976,448)$ found evidence that wage garnishment induces: debtors to quit their jobs and apply for welfare.

What is the appropriate level of wage garnishment? As long as measured income is the basis for the insurance, there must be a compromise between provision of insurance, provision of work incentives, and provision of an incentive to repay debts. High garnishment rates reduce the implicit insurance coverage and induce reductions in work. Low rates of garnishment increase the number of defaultors, reduce the amount that an individual can borrow, and provide more insurance. One must have more information than we currently have to solve this problem, ${ }^{31}$ but labour supply research may provide a rough guide to the appropriate rate of garnishment.

Some jurisdictions have eliminated wage garnishment altogether. ${ }^{32}$ A ban on wage garnishment raises the cost of borrowing for those without non-human capital, reduces the amount of lending and leads to the 
substitution of other collection methods such as harassment. For those with assets, it will lead to seizure of the assets. ${ }^{33}$ The provisions governing exemptions from garnishment are closely related to the provision for discharge through bankruptcy. If wage garnishment is increased, there may be a corresponding increase in bankruptcy ${ }^{34}$ because the discharge available following bankruptcy is more attractive when wage garnishment is high.

\section{Bankruptcy}

Personal bankruptcy has been an extremely controversial procedure in the United States ${ }^{35}$ and Canada, 36 and its growth has been significant, yet there has been relatively little economic analysis of personal bankruptcy. ${ }^{37}$ Meckling (1977) identifies a number of economic elements in personal bankruptcy laws, but he leaves a number of unanswered questions, the most important of which are whether the laws are desirable and whether it might be desirable for debtors to agree to forgo their rights to discharge as part of a contract. The general skepticism of economists concerning the efficiency of bankruptcy legislation ${ }^{38}$ is inconsistent with the growth of the principle in many diverse legal systems over hundreds of years.

It was argued above that provisions that permit partial or total foregiveness of debts (exemptions, compositions, discharge) provide implicit insurance, and mandatory insurance limiting repayment was found to be justified in situations in which over-signalling might occur. Most of the arguments for mandatory discharge parallel the arguments for mandatory insurance, which have been discussed in Rea (1981a). They are as follows: ${ }^{39}$ 
1. Misperception of Risk and Misunderstanding Concerning Remedies

(Federal Trade Commission, 1974).

Consumers will not correctly assess the implications of creditors remedies and will not take into consideration the risk of becoming overextended.

2. Externalities (Fried, 1981, 108)

Given the existence of income tested benefits, private insurance will be discouraged. Mandatory private insurance is needed to make sure that public welfare is not used to fulfill contractual obligations. This argument is not convincing because it implies that we should force low income borrowers to buy their own insurance, a policy that is not consistent with the objectives of the income tested programs (see Rea 1981c).

3. Self-Paternalism (Tullock, 1971, 54)

Collectively we decide to prevent ourselves from being tempted by contracts that we know are not in our long term interest.

\section{Adverse Selection}

As demonstrated in Appendix $B$ and in the insurance literature (Wilson, 1977), the market may lead to an excessive willingness af low risk borrowers to forgo insurance. Mandatory insurance can make both low risk and high risk borrowers better off. This is the most convincing argument for mandatory insurance.

The central problem facing an insurance system is the preservation 
of the incentive to repay loans for those who have not suffered an exogenous decline in the ability to pay. If all assets and future income were turned over to creditors as a result of bankruptcy, discharge would be a formality. When the debtor is allowed to keep a portion of his current assets and present and future income, as is necessary if insurance is to be provided, some moral hazard is inevitable. Exemptions from attachment and garnishment provide implicit insurance, but does it make sense to forgive repayment out of future income, in other words to discharge the debt? Why not have a system of continued garnishment as long as there is a debt outstanding, with some assets exempt from execution? ${ }^{40}$ Depending on future earnings, this may turn out to be a composition or partial forgiveness. Such a system has a substantial real cost in that there is reduced incentive to increase earnings and to accumulate assets. At some point it becomes desirable to terminate the tax on income and the discouragement to asset accumulation. Arrangements such as Part $X$. of the Bankruptcy Act, Chapter XIII in the United States, the Lacombe Law in Quebec and the "Orderly Payment of Debts" scheme proposed by the Ontario Law Reform Commission (1981) set a time limit on the period of repayment ( 3 years in the last proposal). Ordinary bankruptcy essentially sets the period of repayment equal to zero.

As Trebilcock and Schulman (1976) note, there is little incentive to participate in an arrangement if the alternative is immediate discharge. One could also say that there is little incentive to repay when assets fall below the exemption level. The only thing that keeps bankruptcy at reasonable levels is the arm-breaking element implicit in the insurance. The discharged bankrupt may be subject to some social sanctions and will be limited in his future borrowing activities. As described 
above, this arm-breaking is an efficient aspect of an insurance contract in which income (in this case future income) cannot easily be monitored.

\section{Conclusiions}

This paper has demonstrated that the efficient debtor-creditor contract will include some provisions for insurance. This insurance will not be perfect because of the imperfect information that characterizes the debtor-creditor relationship. When the market is likely to lead to excessive creditors' remedies because of excessive signalling, the law can make borrowers and lenders better off by limiting their use. Nevertheless, some degree of harassment and limitation on discharge is efficient in order to control moral hazard. . The insurance is best provided by overall exemptions from seizure and garnishment rather than specific exemptions for secured creditors. It will be in the interests of borrowers to agree to repossession and deficiency judgments if assets exceed these levels. 


\section{APPENDIX A \\ Secured Credit, Tastes Stochastic}

Let $S$ equal the (new) selling price of a good sold on credit or the balance owed on a loan in which the good is the collateral. Utility is $U(Y-S, X)$ in the event that their good is consumed, where $Y$ is the individual's income and $X$ is a stochastic index of the utility of the good. Without loss of generality we can scale $X$ as the dollar amount that the consumer would accept to give up the good. $f(X)$ is the probability density function of $X$.

Let $V(Y+I-S)$ be the utility in the event that the good is not consumed. I is the amount that will be credited to the consumer upon default, gross of the amount owed. There will be some value of $X$ at which the consumer is indifferent between consuming the good and defaulting, given the value of $I$. At this point $X=I$ and

$$
U(Y-S, I)=V(Y+I-S)
$$

Whenever I exceeds $X, U<V$ and the consumer defaults. The expected utility of the consumer $U^{*}$ is:

$$
U^{*}=\int_{I}^{\infty} U(Y-S, X) f(X) d X+\int_{0}^{I} V(Y+I-S) f(X) d X
$$

Maximizing the expected utility with respect to I, taking account of the fact that $S$ depends on $I$, gives: 


$$
\begin{gathered}
\int_{I}^{\infty} U^{\prime}(Y-S, X)\left(-\frac{\partial S}{\partial I}\right) f(X) d X+\int_{0}^{I} V^{\prime}(Y+I-S)\left(1-\frac{\partial S}{\partial I}\right) f(X) d X \\
+f(I)(V(Y+I-S)-U(Y-S, I))=0
\end{gathered}
$$

The last term equals zero from equation 1. Therefore,

$$
\int_{I}^{\infty} U^{\prime}(Y-S, X)\left(-\frac{\partial S}{\partial I}\right) f(X) d X+\int_{0}^{I} V^{\prime}(Y+I-S)\left(1-\frac{\partial S}{\partial I}\right) f(X) d X=0
$$

In the situation in which the good is consumed -or rejected in the same period as the sale, the selling price must be such that the expected revenues equal the expected expenses:

$$
\begin{aligned}
P & =\int_{I}^{\infty} f(X) d X=\text { Probability that no default. } \\
M & =\text { Cost of retail sale (store expenses) } \\
H & =\text { Wholesale cost } \\
E & =\text { Expenses of repossession } \\
D & =\text { Depreciation (new minus used price) } \\
S & =W+M+(1-P) E-(1-P)(H-D)+(1-P) I \\
S & =P(H+M)+(1-P)(I+E+D+M)
\end{aligned}
$$

The credit selling price consists of the probability that there is no default multiplied by the retail price for cash customers plus the probability of default multiplied by the cost of transferring the good to another customer. This includes the gross amount paid to the defaulting 
consumer, the expenses of repossession, the depreciation and the cost of resale.

$$
\frac{\partial S}{\partial I}=(I-P)-f(I)(H-E-D-I)
$$

Essentially the same model holds if a loan was made by a third party, with the good as collateral. Let $L$ equal the default-free amount of the loan and $S$ equal the amount that must be paid back in order to cover defaults:

$$
S=L+(1-P)(I+E-(H-D))
$$

$\frac{\partial S}{\partial I}$ is the same as in equation 7 . Define $T$ to equal the net proceeds of repossession in both cases:

$$
T=W-E-D
$$

Substitution of 7 into 4 gives

$$
\begin{aligned}
& \left.\int_{I}^{\infty} U^{\prime}(Y-S, X)(1-P)-f(I)(T-I)\right) f(X) d X \\
& =\int_{0}^{I} V^{\prime}(Y+I-S)(P+f(I)(T-I)) f(X) d X
\end{aligned}
$$

Obviously there is no simple solution to the problem of determining I in the general case. However, if there is no risk aversion, $U^{\prime}(Y-S, X)=V^{\prime}(Y-S+I)$ for all $X$ and the solution to equation 10 is $I=T$ and $S=. H+M$ (or $S=L$ in equation 8 ). The consumer bears all of the risk if changes in his taste and he is liable for any deficiency (when $T<s$ ). 
APPENDIX B

Secured Credit, Income Stochastic

When income is stochastic, there may be some level of income, $\bar{Y}$, such that the individual is indifferent between consumption and default: The critical level of income will depend on the amount that is credited to the consumer after repossession:

$$
\bar{\gamma}=g(I)
$$

$U(Y-S)$ is the utility if there is no default and $V(Y+I-S)$ is the utility if there is default. At the critical income level:

$$
U(\bar{Y}-S)=V(\bar{Y}+I-S)
$$

Note that for a normal good, when I=S,

$$
U^{\prime}(\bar{Y}-S)>V^{\prime}(\bar{Y})
$$

Default will occur whenever income falls below $\bar{Y}=g(I)$. EXpected utility equals

$$
U^{*}=\int_{g(I)}^{\infty} U(Y-S) f(Y) d Y+\int_{0}^{g(I)} V(Y+I-S) f(Y) d Y
$$

The first order condition is 


$$
\begin{aligned}
& \int_{g(I)}^{\infty} U^{\prime}(Y-S)[(I-P)-f(g(I))(T-I)] f(Y) d Y \\
& \quad=\int_{0}^{g(I)} V^{\prime}(Y+I-S)[P+f(g(I))(T-I)] f(Y) d Y
\end{aligned}
$$

If the good is an absolute necessity, $U^{\prime}(\bar{Y}-S)=V^{\prime}(\bar{Y})$ when $U(\bar{Y}-S)=V(\bar{Y})$ and the good will be purchased as long as $Y \geq S$. The optimal I is $S-\varepsilon$ where $\varepsilon \rightarrow 0$. 
APPENDIX C

Arm-Breaking to Control Moral Hazard

The moral hazard that is assumed to exist is the inability of the consumer to monitor the state of the world that has occured. The probability of a loss is assumed exogenous. For simplicity it is assumed that there are only two time periods. In the first period the consumer borrows and in the second period he repays the loan, depending on the income that he receives. The income is exogenously determined and depends on the state of the world, but the lender is unable to determine which state has occured. It is assumed that there are only two states that can occur in the second period. In the first, the consumer's income is maintained at the period 1 level, and in the second, it falls as a result of some loss.

The following notation is used:

$C \quad$ = consumption

$W(C)=$ utility in period 1

$U(C)=$ utility in period 2 , if no loss of income

$V(C)=$ utility in period 2 , if loss of income

$r \quad=$ default free interest rate

$L /(1+r)=$ amount of loan

$p=$ probability that no loss of income in period 2

$Z \quad$ = amount of loss of income

I. = amount of loan forgiveness

$Y=$ income of borrower

Since the vendor must earn a market rate of interest, the borrower will repay an amount $\left(\frac{l-p}{p}\right) I$ in addition to $L$ in the event that he has not suffered a loss of income. Otherwise he will pay back L-I . 
If the loss of income could be observed, the borrower would maximize his expected utility

$$
W\left(Y+\frac{L}{1+r}\right)+p U\left(Y-L-\left(\frac{I-p}{p}\right) I\right)+(1-p) V(Y-L-Z+I)
$$

by choosing a level of borrowing $(L)$ and the amount of loan that will be forgiven (I) in the event of a loss of income $(Z)$. In order to prevent borrowers from claiming that they have lost income, an amount of punishment, called arm-breaking, must be chosen that is just painful enough to induce those who have not lost $Z$ to repay their loans. The amount of pain inflicted on all of those who ask to be released from part of their debt, evaluated as a loss of utility, is

$$
-\left[U(Y-L+I)-U\left(Y-L-\left(\frac{T-p}{p}\right) I\right)\right]
$$

It is assumed that the arm-breaking does not affect the marginal utility of income. If it took a form that reduced the marginal utility of income, such as imprisonment, the value of the forgiveness would be reduced.

The optimal arm-breaking contract is one that maximizes expected utility

$$
\begin{aligned}
U^{*}= & W\left(Y+\frac{L}{1+r}\right)+p U\left(Y-L-\left(\frac{1-p}{p}\right) I\right) \\
& +(1-p) V(Y-L-Z+I) \\
& -(1-p)\left[U(Y-L+I)-U\left(Y-L-\left(\frac{1-p}{p}\right) I\right)\right]
\end{aligned}
$$

With respect to $L$ and $I$. The first order conditions are: 


$$
\begin{gathered}
W^{\prime}\left(Y+\frac{L}{1+r}\right) /(I+r)=U^{\prime}\left(Y-L-\left(\frac{I-p}{p}\right) I\right)\left(\frac{l}{p}\right) \\
U^{\prime}\left(Y-L-\left(\frac{l-p}{p}\right) I\right)=p\left[V^{\prime}(Y-L-Z+I)-U^{\prime}(Y-L+I)\right]
\end{gathered}
$$

For the optimal value of $I$, equation 19 indicates that the consumer will borrow until the (discounted) marginal utility of income in period 1 equals the marginal utility of income in period 2, taking account of the fact that there is an additional cost associated with the enforcement mechanism. If the arm-breaking were not necessary, the right hand side of equation 19. would be

$$
U^{\prime}\left(Y-L-\left(\frac{1-p}{p}\right) I\right)
$$

which indicates a lower marginal cost of borrowing. If the loan were to be repaid regardless of the state of the world, the right hand side would be

$$
p U^{\prime}(Y-L)+(1-p) V^{\prime}(Y-L-Z)
$$

which is not necessarily higher than the right hand side of equation 19.

Given the optimal loan, equation 20 indicates that the loan forgiveness will be below the optimal insurance level $\left(U^{\prime}=V^{\prime}\right)$ because the arm-breaking adds to the cost of insurance. It can be shown that the optimal amount of forgiveness is zero unless there is a sufficiently large loss, at which point successively larger amounts of the loan are forgiven. 41 
APPENDIX D

Arm-Breaking as a Signal

Arm-breaking may perform a signalling role in unregulated credit markets. Low risk borrowers may voluntarily offer ex ante to have their arms broken in the event of default as a signal that they will in all likelihood repay their loans. High risk customers will be reluctant to offer such a contract because of the greater probability of default. The implications of this type of behaviour for public policy will be explored with a simple model. Assume that there are only two states of the world, one in which a loan is repaid and another in which there is default. There is no partial forgiveness of loans. The probability of default is exogenous and ex post observable (no moral hazard) but ex ante is known only to the borrowers. In such a world the lender, faced with a constant cost of funds, will be willing to lend to high risk customers at a higher interest rate than he would be willing to lend to low risk customers, but he cannot differentiate between the two without some signal. It is assumed that the quantity of borrowing is not used as a signal.

In Figure $4 i_{H}$ is the break even interest rate for high risk customers given the risk of default. $i_{L}$ is the rate for low risk customers, and $i_{H L}$ is the average of the two groups, weighted by the size of each group. The two types of borrowers will be willing to offer to have their arms broken in the event of default if they can sufficiently reduce the cost of borrowing. The indifference curves for the two groups are shown in Figure 1. The indifference curves for the low risk group (solid line $U_{L}$ for instance) are flatter than for the high risk group (dashed line $U_{H}$ for instance) because of their lower probability of experiencing the pain. Given the way in which the curves are drawn, in 
FIGURE 4

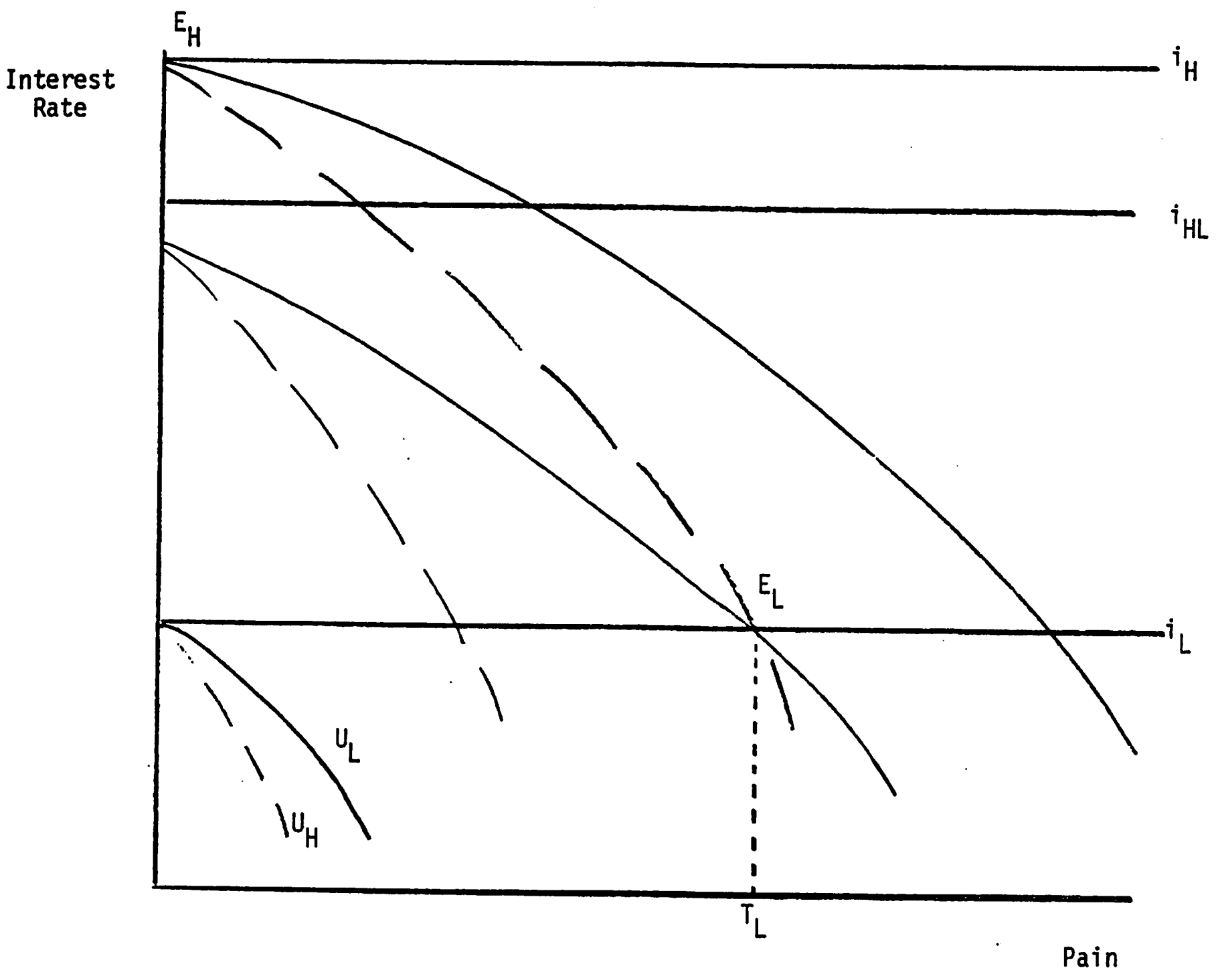


particular the ratio of high risk to low risk borrowers and the difference in probabilities, it may pay the low risk borrower to offer to accept an amount of pain $T_{L}$ in order to signal that they are low risk customers who can be charged $i_{L}$. This is the minimum amount of pain that they must endure. Any smaller amount coupled with the lower interest rate would appeal to high risk customers as we11. Note that the point $E_{L}$ is on the high risk indifference curve passing through $E_{H}$.

The set of contracts $E_{H}$ and $E_{L}$ in Figure 4 is an equilibrium set of contracts because no borrower or lender has an incentive to propose an alternatives, but the equilibrium may not be Pareto efficient. If the sorting effects of the arm-breaking could be achieved at a lower real cost, both groups could be made better off. It may be possible for both low and high risk groups to be made better off by a combination of contracts in which low risk groups subsidize high risk groups. Wilson (1977) and Rothschild and Stiglitz (1976) demonstrate this in the insurance context.

The subsidized contract proposed for insurance markets may not be practical in the consumer credit context, but there is one situation in which there is a practical public policy which can make both groups better off. Assume that there is an imperfect method of screening that can be used to assign individuals to a risk classification. ${ }^{42}$ The screening method is assumed to depend on factors not under the control of the borrower. ${ }^{43}$ The assignment procedure would impose the risk of misclassification on low risk borrowers. Allowing for the disutility of this risk and the cost of subsidizing misclassified high risk borrowers, the certainty equivalent interest rate for low risk borrowers (before they know the result of the classification) is $i *$ in Figure 5 . The actual rate, 
38

FIGURE 5

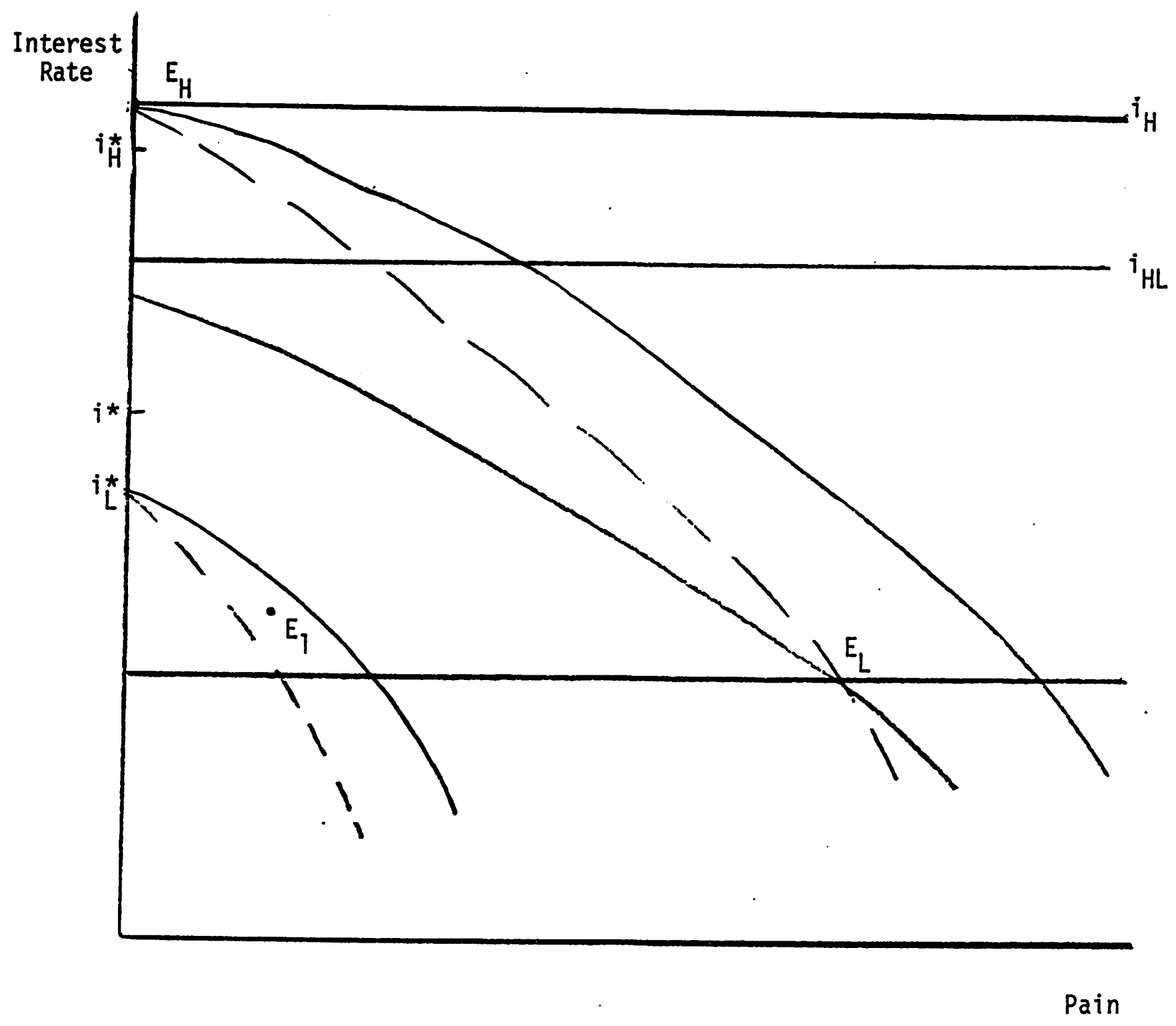


$i_{L}^{*}$ would be even lower. ${ }^{44}$ If an equilibrium could be achieved at $i_{L}^{*}$, all of the low risk borrowers would be better off ex ante. The misclassified high risk borrowers would be substantially better off, and the others would be somewhat better off because they would be subsidized by misclassified low risk borrowers. The rate charged this group would be $i_{H}^{*}$.

Unfortunately, a private market would not establish an equilibrium at $i_{L}^{*}$. First, misclassified low risk borrowers would choose to signal and would move to $E_{L}$, leaving the correctly classified high risk borrowers at $E_{H}$. Second, lenders have an incentive to offer arm-breaking contracts such as $E_{1}$ to attract low risk borrowers from $i_{L}^{*}$. Faced with the loss of a contract at the interest rate $i_{L}^{*}$, misclassified high risk borrowers would choose $E_{1}$ over $E_{H}$. Successive attempts to attract. low risk customers would continue until the original equilibrium $\left(E_{L}, E_{H}\right)$ was restored. 45

The example illustrates that the market may fail to support a preferred process of imperfect statistical screening. The imperfect screening method is preferred by low risk borrowers if the cost of subsidizing misclassified high risk borrowers and the risk factor (for misclassification) are less than the cost of signalling. The failure in . the market occurs because high risk groups cannot bind themselves to the results of the screening mechanism. An obvious solution is to have the government impose the terms of the contract by banning arm-breaking contracts. Once this signal is banned the market can provide the two types of contracts $i_{L}^{*}$ and $i_{H}^{*}$. 
The example just described was one in which the low risk borrowers would prefer signalling to subsidizing high risk borrowers, in the absence of a cheaper statistical screening device. If the number of low risk customers is large relative to the number of high risk customers or if the difference is small, a pooling contract could emerge. In Figure $6 E_{H L}$ is preferred by the low risk to $E_{L}$. The problem associated with $E_{H L}$ is that it is not a conventional equilibrium. Firms will be tempted to offer contract such as $E_{1}$, which make $E_{H L}$ unprofitable by drawing away low risk customers. Wilson (1977) specifies behaviour on the part of sellers (lenders in this case) that allows $E_{H L}$ to be a (Wilson) equilibrium. If the market is characterized by Figure 6 , the mandatory elimination of arm-breaking contracts would el iminate the inefficient tendency of firms to experiment with contracts such as $E_{1} \cdot 46$ Riley (1979) argues (in an insurance context) that although $E_{H L}$ is Pareto preferred to $E_{L} E_{H}$, the market will generate the latter as sellers anticipate that a pooling contract that is offered can be made unprofitable by a riskless new contract offered by a second firm. It follows that both high and low risk groups can be made better off by a ban on arm-breaking. 
FIGURE 6

:

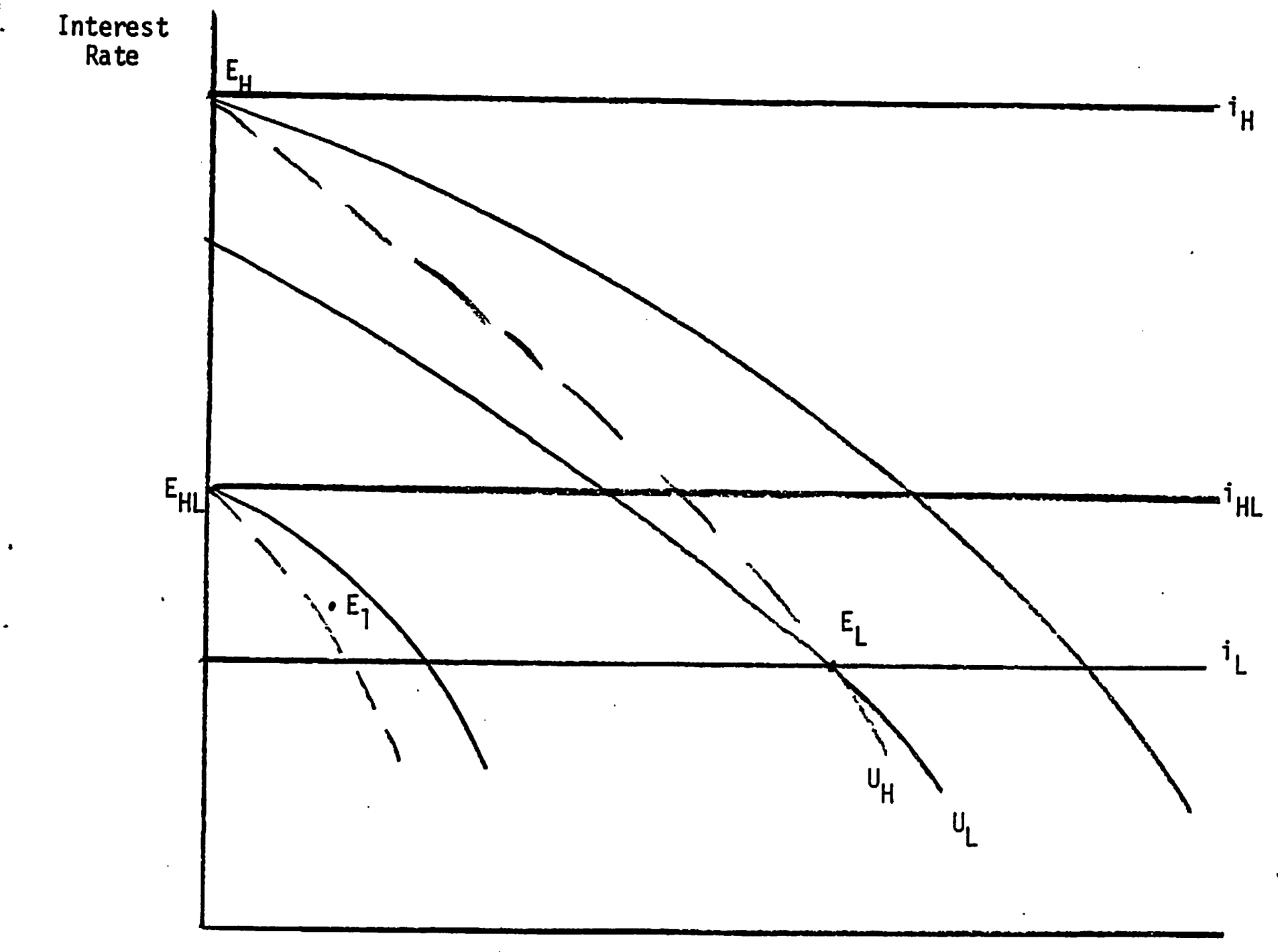

Pain 


\section{BIBLIOGRAPHY}

Apilado, Vincent P., Joel, J. Dauten, and Douglas E. Smith (1978), "Personal Bankruptcy", Journal of Legal Studies, 7, 371-392.

Benjamin, Daniel K. (1978), Economic Inquiry, XVI, 333-359.

Blackstone, William (1766), Commentaries on the Laws of England, Book 2, Oxford: The clarendon Press.

Canada (1970), Bankruptcy and Insolvency, Report of the Study Committee on Bankruptcy and Insolvency Legislation.

Caplovitz, David (1974), Consumers in Trouble, New York: Macmillan.

Cayne, David and M.J. Trebilcock (1973), "Market Considerations in the Formation of Consumer Protection Policy", University of Toronto Law Journal, $23,396$.

Fried, Charles (1981), Contract as Promise, Cambridge, Massachusetts, Harvard University Press.

Gilmore, Grant (1965), Security Interests in Personal Property.

Huber, Joel (1978) Consumer Perception of Credit Insurance on Retail Purchases, Credit Research Center, Krannert Graduate School of Management, Purdue University.

Jaffee, Dwight M. and Thomas Russe11 (1976), "Imperfect Information, Uncertainty, and Credit Rationing", Quarterly Journal of Economics, $X C, 657-666$.

Johnson, Robert W. (1978), Cost/Benefit Analysis of Creditors' Remedies, Credit Research Center, Krannert Graduate School of Management, Purdue University.

Law and Contemporary Problems (1977), Vo1.41, The Economics of Bankruptcy Reform.

Leff, Arthur (1970), "Injury, Ignorance and Spite - the Dynamics of Coersive Collection", Yale Law Journa 1, 80, 1-46.

Meckling, William H. (1977), "Financial Markets, Default, and Bankruptcy: The Role of the State", Law and Contemporary Problems, XLI, 13-38.

Michelman, Irving S. (1970), Consumer Finance: A Case History in American Business, New York: Augustus M. Kelley.

Ontario Law Reform Commission (1981), Report on the Enforcement of Judgment Debts and Related Matters. 
Ordover, Janusz and Andrew Weiss, "Information and the Law: Evaluating Legal Restrictions on Competitive Contracts", American Economic Review, $71,399-404$.

Polinsky, A. Mitchell and Steven Shavell . (1979) "The Optimal Tradeoff Between the Probability and Magnitude of Fines", American Economic Review, $69,880-892$.

Rea, Samuel A. (1981a), Disability Insurance and Public Policy, University of Toronto Press.

Rea, Samuel A. (1981b), "Workmen's Compensation and Occupational Safety Under Imperfect Information", American Economic Review, 71, 80-93.

Rea, Samuel A. (1981c), "Private Disability Insurance and Public Welfare Programs", Public Finance, XXXVI, 84-98.

Riley, John G. (1979), "Informational Equilibrium", Econometrica, 47, $331-359$.

Rothschild, Michael and Joseph Stiglitz (1976), "Equilibrium in Competitive Insurance Markets: An Essay on the Economics of Imperfect Information", Quarterly Journal of Economics, XC, 629-650.

Shay, Robert (1979), "Consumer Protection in Credit Markets: An Analysis of Regulatory Reform", in Franklin Edward (ed.) Issues in Financial Regulation, McGraw Hili, 1979, 217-258.

Shave11, Steven (1981), "Notes on Contract", unpublished.

Shuchman, Phillip (1969), "Profit on Default: An Archival Study of Automobile Repossession and Resale", Stanford Law Review, 22, 20-66.

Shuchman, Phillip (1978), "Field Observations and Archival Data on Exegution Process and Bankruptcy in Jersuleum", American Bankruptcy Law Journal, 52, 341-367.

Spence, A. Michael (1974), Market Signalling, Cambridge, Massachusetts, Harvard University Press.

Spence, A. Micahel and Richard Zeckhauser (1971), "Insurance, Information, and Individual Action", American Economic Review, LXI, 380-387.

Stanley, David T. and Marjorie Girth (1971), Bankruptcy: Problem, Process Reform, Washington, D.C., Brookings Institution.

Stiglitz, Joseph and Andrew Weiss, "Credit Rationing in Markets with Imperfect Information", American Economic Review, $71,39-410$.

Trebilcock, Michael and Donald Dewees (1981), "Judicial Control of Standard Form Contracts", in Burrows and Veljanovski, The Economic Approach to Law, London: Butterworths. 
Trebilcock, Michael and Arthur Shulman, "The Pathology of Credit Breakdown, McGill Law Journal, 22, 415-467.

U.S., Federal Trade Commission (1974), Memorandum, April 19, Bureau of Consumer Protection.

U.S. National Commission on Consumer Finance (1972a), Report.

U.S. National Commission on Consumer Finance (1972b), Iechnical Studies, 6 Vol.

Warren, Charles (1935), Bankruptcy in United States History, Cambridge, Massachusetts, Harvard University Press.

Wilson, Charles (1977), "A Model of Insurance Markets with Incomplete Information", Journal of Economic Theory, 16, 167-207.

Yaeger, Frederick C. (1974), "Personal Bankruptcy and Economic Stability", Southern Economic Journal, 41, 96-102.

Ziegel, Jacob S. and Benjamin Geva (1981), Commercial and Consumer Transactions, Toronto, Edmond-Montgomery. 
FOOTNOTES

1. See Shavel1 (1981).

2. See Trebilcock and Dewees (1981).

3. Rea (1981b) shows that government intervention in the presence of misperception of risk can make workers worse off.

4. U.S. National Commission on Consumer Finance (1972b).

5. This only applies when interest rates are unregulated. If borrowers misunderstand the implications of contracts, this approach cannot be used to determine the optimality of changes in creditors' remedies.

6. Borrowing for non-corporate business purposes raises many of the same issues.

7. Blackstone $(1766,473)$. Extension of laws to non-traders may be related to the increased importance of consumer durables.

8. Stiglitz and Weiss (1981).

9. Usually the borrowers pays separately for this insurance. Credit insurance is generally offered by primary lenders but is offered by only 10 per cent of retailers (Huber, 1978, 5). Coverage for the balance owed in the event of death or dismemberment costs .15 per cent per month for one retail store (Huber, 1978, 3).

10. Extension of the policy described in the previous footnote to cover property loss and unemployment raises the charge to .5 per cent per month. Normal payments would be made by the insurance carrier during the period of unemployment. A Vancouver insurance firm recently announced that it would continue payments on a car for up to 10 months 
if the insured borrower became unemployed. The policy would cost about 2.6 per cent of the monthly payments. Globe and Mail, December 7, 1981, p.1.

11. The usual explanation for these provisions is that recipients of wages and alimony are not assumed to know the financial position of their debtors. Learned Hand stated that "the statute was intended to favor those who could not be expected to know anything of the credit of their employer, but who must accept the job as it comes...", In re Lawson Electric Co. Inc. Ex Parte Bernan (1924) $300 F 736$ (S.D. N.Y.).

12. See Shuchman (1969).

13. Gilmore $(1965,1185-6)$.

14. Federal Trade Commission (1974).

15. Canada $(1970,111)$.

16. Ontario Law Reform Commission (1981).

17. Ontario, Execution Act, s.7(1).

18. Obviously such a rule must also require that the creditor make a reasonable effort to maximize the resale value. One method of enforcing this is to enforce the deficiency only if the creditor has demonstrated that he maximized the resale value net of costs. Shuchman (1969) discusses some of the potential abuses that can occur when the law allows the creditor flexibility.

19. U.S. National Commission on Consumer Finance (1972b, V, 266-7).

20. The United States National Commission on Consumer Finance (1972a, 25) 
recommended that contracts be permitted to include attorney's fees up to 15 per cent.

21. U.S. Federal Trade Commission $(1974,424)$.

22. Ontario Law Reform Commission (1981, III, 34-37), Ziegel and Geva $(1981,1128)$.

23. U.S. National Commission on Consumer Finance (1972a, 29). The creditor would be allowed to choose between repossession without a deficiency judgment and a personal judgment for the entire amount.

24. Ontario Law Reform Commission (1981, II, 90).

25. I can find no economic explanation for the proposal that the repossession should be prohibited if the debtor's equity exceeds some percentage (say 67 per cent). s.35 of the Ontario Consumer Protection Act requires a prior consent order in this situation.

26. The landlord-tenant relationship exhibits some of the same problems as the contracts described here. In the Ontario Landlord and Tenant Act the tenant must continue to pay rent despite the landlord's failure to maintain the premises, but the tenant may apply to a court for a rent reduction to allow for repair costs. (s.96(3)). In an emergency the tenant may have critical repairs done and deduct the cost from his rent, but the landlord may contest these costs in court.

27. Benjamin (1978) examines contracts of this type but does not consider the insurance motive.

28. This approach was suggested in part by the model in Polinsky and Shavell (1979). Jaffee and Russell (1976) have a model in which the defaultors are fined. This is inconsistent with the insurance motive because those who cannot pay debts cannot pay fines. 
29. Michelman $(1970,80)$ notes that in the early 1900 's loan offices would employ a "female employee called a 'bawlerout' whose job was to go to the place of employment of the deliquent borrower and bawl him out in front of all his colleagues for not paying his bills". Johnson $(1978,40)$ says that this practice is prohibited because it is immoral. An economic explanation is that it is prohibited because of the externalities on fellow employees and the likelihood that it might ultimately cost the employee his job, thereby reducing the chances of repayment.

30. Equation 17 in Appendix C.

31. Spence and Zeckhauser (1971) discusses the general solutions to the insurance problem in which income, rather than the actual loss, is observable. One complication here is that the garnishment will cease when the debt is repaid.

32. New Brunswick, Pennsylvania and Texas.

33. According to Caplovitz $(1974,257)$ the lack of garnishment in Pennsylvania induces creditors to seize personal and real property.

34. There is some evidence of this. See Apilado et al (1978).

35. Warren (1935).

36. Canada (1970).

37. Apilado et al (1978) examines the effect of state bankruptcy laws on the incidence of bankruptcy, and Yaeger (1974) examines the response of bankruptcy to economic conditions.

38. Conference on the Economics of Bankruptcy Reforms, Law and Contemporary Problems, XLI (1977). 
39. There are some less plausible explanations presented in Law and Contemporary Problems (1977). These include tax incentives, preventing extension of credit, incentives to turn over assets and reductions in collection costs.

40. Israel has a similar system (Shuchman, 1978, 356).

41. For example if $p=.9, y=30,000, U=V=\ln (C)$ and the loan is held constant at 10,000 the loan will be repaid if the loss is less than 10,526 .

42. The assignment is assumed costless for purposes of the argument, but the cost can easily be worked into the analysis. The cost will always be borne by the low risk borrower. If a lender attempts to pass the cost on to the high risk borrowers, the high risk borrowers will simply declare themselves to be high risk to other lenders, thereby avoiding screening costs.

43. The screening method is assumed to be an index in Spence's (1974) terminology.

44. There is a possibility that $i^{\star}$ might lie below $i_{L}^{\star}$.

45. $i_{L}^{*}$ might be a Wilson (1977) equilibrium but not a Riley (1979) equilibrium. See below.

46. Ordover and Weiss (1981) make a similar point with respect to product failure. 